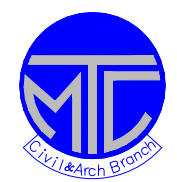

\title{
ICCAE
}

Military Technical College

Kobry Elkobbah, Cairo, Egypt

\author{
7 th International Conference \\ On Civil \& Architecture \\ Engineering
}

\section{Petro-mechanical characteristics of the Eocene and Miocene foundation carbonate rocks of New Cairo City}

\author{
Mostafa A. M. SAAD*, Samir A. AWAD** \& Waleed A. AGILA** \\ * Department of Civil Eng., Higher Technological Institute, Tenth of Ramadan, Egypt \\ **Department of Geology, Ain Shams University, 11566 Cairo, Egypt
}

\begin{abstract}
Being the inherent attributes of carbonate rocks, the petrographic characteristics such as mineral composition, texture, detrital materials, porosity and microstructures are very important factors that influence their compressive strength. Different in situ and laboratory tests were conducted to investigate petrographic characteristics and compressive strength of the Eocene and Miocene carbonate rocks of New Cairo City. The results show that the uniaxial compressive strength of carbonate rocks increase with decrease allochem fragments, idiotopic crystals, detrital materials and porosity. On the other hand, their uniaxial compressive strength increase with increase cemented materials, hypidiotopic crystals within the rock. The relationships of calcite cemented materials crystal size with rock strength indicated that; the fine crystals have best relations with rock strength parameters than the large crystals.
\end{abstract}

Keywords: petrographic characteristics, carbonate rocks, uniaxial compressive strength, New Cairo City

\section{Introduction}

The petrographic characteristics of carbonate rocks have a constructive effect on their macro-mechanical properties. Recently, studies on the relationship between petrographic characteristics of carbonate rocks and macro-mechanical properties are mainly focused on the influence of rock microstructures on the rock strength. Many researchers have investigated the correlation between grain size, texture, porosity, mineralogical composition and rock strength of carbonate rocks and have come out with some interesting viewpoints (Hugman and Friedman, 1979, Hatzor and Palchik, 1997 and 1998, Onodera and Asoka, 1980, Eberhardt et al., 1999 and Palchik and Hatzor, 2004). Hatzor and Palchik (1997 and 1998) show that a dense (less porosity) or a finer (a smaller grain size) texture of dolomite resulted in greater strength. Eberhardt et al. (1999) present the effects of grain size on the initiation and propagation thresholds of stress induced 
brittle fracture in crystalline rocks with similar mineralogical compositions. Palchik and Hatzor (2004) revealed that the uniaxial compressive strength in porous chalks decrease with increasing porosity.

\section{Location and Litho-Stratigraphy of the Study Area}

Several new settlements have been constructed in the area East of the Greater Cairo. The most important new settlement in Egypt is New Cairo City. This new city is situated to the East of Capital Cairo City, between latitudes $29^{\circ} 55^{\prime} \mathrm{N}$ and $30^{\circ} 10^{\prime} \mathrm{N}$, and longitudes $31^{\circ} 20^{\prime} \mathrm{E}$ and $31^{\circ} 40^{\prime} \mathrm{E}$ (Figure 1). The New-Cairo City is bounded between Cairo-Suez desert road from the North, El-Maadi - El-Qattamiya road from the South, Ring road from the West and Gebel El-Anqabiya from the East. It is about $15.00 \mathrm{~km}$ far from El-Maadi and El-Darrasa, $10.00 \mathrm{~km}$ from Nasr City and well connected with the existing road network.

The field studies showed that the exposed rocks in the study area range in age from Upper Eocene to Pliocene (Figure 2). The Upper Eocene (Wadi Hof Formation) occupies the southern part of the study area $\left(3^{\text {rd }}\right.$ Settlement) and consists of claystone intercalated with light to dark brown limestone, dolostone, marl and some weakly cemented sandstone beds. The Oligocene rocks occupy the middle part of the study area ( $5^{\text {th }}$ Settlement) and consist of varicolored, unstratified, medium to coarse-grained sands, cross-bedded sandstones and pebble beds with silicified wood and sedimentary quartzite (Gebel Ahmer Formation). The top of the Gebel Ahmar Formation in many localities is covered with thin basaltic flows representing a volcanic phase in the Oligocene history and mostly associated with faults in the study area. The Middle Miocene (Marine Miocene unit) occupies the northern part of the study area $\left(1^{\text {st }}\right.$ Settlement and its surrounding areas, Figure 1) and consists of sandstone, limestone, dolostone interbedded with claystone beds. The Upper Miocene and Pliocene sediments consist mainly of friable sand and gravels intercalated with thin beds of clay and occupy the most northern part of the study area (South of Cairo-Suez road).

\section{Materials and Methods}

Eight Upper Eocene carbonate rock samples were collected from three sections along the southern scarp of $3^{\text {rd }}$ Settlement population area and one Upper Eocene and thirteen Middle Miocene carbonate rock samples were collected from base of foundation structures at $3^{\text {rd }}$ and $1^{\text {st }}$ Settlements population areas, respectively, (Figure 3, and Table 1). Thin sections of the carbonate rock samples were investigated under the optical microscope to identify their petrographic components. The classification and terminology of Folk (1959 and 1962) and Dunham (1962) are used to describe their petrographic texture. Two methods were used to measure the uniaxial compressive strength for the studied rock samples. The first one was in situ and conducted using N-type Schmidt hammer (indirect method) while the other was carried out using a universal testing machine. Cubes of carbonate rock samples were trimmed and directly used in the universal testing machine. 


\section{Results}

\section{1- Petrographic Characteristics of Carbonate Rocks}

A quantitative analysis of the petrographic characteristics of the carbonate rocks was carried out on their thin sections using standard polarizing microscope. This includes the examination of allochem skeletal grains, orthochem crystal size, crystal shape, rockforming minerals, cement, detrital components, and porosity.

The Upper Eocene carbonate rock samples are dominated by orthochems relative to allochems (Table 2). Sparry calcite and dolomite cement are major constituents ranging between $2.00 \%$ and $32.00 \%$; (with an average of $12.60 \%$ ) and between $0.00 \%$ and $55.00 \%$ (with an average of $32.44 \%$ ); respectively. The majority of sparry calcite crystals are neomorphic, while the dolomite cement is range from fine to medium crystalline crystals. On the other hand, allochems are represented mainly by skeletal grains $(0.00 \%$ to $40.00 \%$ with an average of $13.11 \%)$ which are arranged according to their abundance as plecypods, algae, small forams and echinid debris. The non-skeletal grains consist mainly of ooids grains that are represented in one sample with a value $5.00 \%$. On the other hand, the detrital components are made up mainly of sub-rounded to rounded quartz grains $(15.00 \%$ - 35.00\%; average $28.88 \%)$, argillaceous materials (0.00\% - 20.00\%; average $7.00 \%)$, and trace amounts of iron oxides, glauconite, feldspars grains and silica cement (Table 2).

Texturally, the skeletal allochems are predominantly medium sand-sized and well to very well rounded. The grains display no contacts. Both fabric and non fabric-selective porosity types were recorded. The dominant pore shapes are non fabric-selective being vuggy and fractures. The fabric-selective type is represented by moldic and intra-particle pores. According to Folk (1959) and Dunham (1962) classifications the Upper Eocene carbonate rock samples are classified as sandy dolomicrosparite (mudstone to wackestone), sandy argillaceous dolomicrite (mudstone), sandy dolomicrite (mudstone) and sandy biomicrosparite (wackestone/ packstone), (Table 2, and Figures 4 to 8).

On the other side, the Middle Miocene carbonate rock samples are more dominated by orthochems relative to allochems (Table 3). Sparry calcite and dolomite cement are major constituents ranging between $0.00 \%$ and $60.00 \%$; (with an average of $24.08 \%$ ) and between $0.00 \%$ and $52.00 \%$ (with an average of $34.90 \%$ ); respectively. The micrite is represented in one sample with a value $45.50 \%$. The majority of sparry calcite crystals are neomorphic, while the dolomite cement is fine crystalline dolomites. On the other hand, allochems are represented mainly by non-skeletal grains $(0.00 \%$ to $25.00 \%$ with average 9.92\%) which are arranged according to their abundance as intraclast and pellets. The skeletal grains consist mainly of plecypods, ostracods, small forams, and bivalvia $(0.00 \%$ to $10.00 \%$ with average $2.81 \%)$. On the other hand, the detrital components are made up mainly of sub-angular to sub-rounded quartz grains $(2.00 \%$ to $22.00 \%$; average $8.12 \%$ ), argillaceous materials (2.00\% to $10.00 \%$; average $4.92 \%$ ), iron oxides (1.00\% to $5.00 \%$; average $2.69 \%$ ), rock fragments are composed mainly of quartz crystals with suture contact of metamorphic origin (Quartzite rocks of Oligocene age). Its values range from $0.00 \%$ to $5.00 \%$ with an average of $1.92 \%$, and trace amounts of glauconite and feldspars grains (Table 3 ).

Texturally, the skeletal allochems are predominantly medium sand-sized and well to very well rounded. The grains display no contacts. Both fabric and non fabric-selective 
porosity types were recorded. The dominant pore shapes are non fabric-selective being vuggy and fractures. The fabric-selective type is mainly represented by moldic and intraparticle pores. According to Folk (1959) and Dunham (1962) classifications the Middle Miocene carbonate rock samples are considered as dolomicrite (mudstone to packstone), argillaceous sandy biosparite (wackestone/ packstone), pelmicrite (wackestone) and intramicrosparite (wackestone), (Table 3, and Figures 9 to 13).

The studied carbonate sediments are affected by different diagenesis processes, such as neomorphism, internal filling, dissolution and dolomitization diagenesis processes.

- Neomorphism is occurred as aggrading neomorphism, where a mosaic of finely crystalline carbonate is replaced by a coarser sparry calcite (Figures 6 and 8 for the Upper Eocene rocks, and Figures 9 and 11 for the Middle Miocene rocks).

- Internal fillings are commonly encountered in the examined carbonate rocks. Calcite and dolomite coarse cement crystals are found as fracture and cavity filling (Figures 4 and 12 for the Upper Eocene and Middle Miocene rocks respectively).

-Dissolution is occurred in the studied carbonate rocks as leaching fossil allochems (mouldic porosity), vugs and intra-particle (Figure 6 for the Upper Eocene rocks, and Figures 9, 11, 12 and 13 for the Middle Miocene rocks).

-Dolomitization process is a common process occurred during the meteoric/seawater mixing zone diagenesis for Upper Eocene and Middle Miocene carbonate rocks at New Cairo City (Figures 4 and 5 for the Upper Eocene rocks, and Figures 12 and 13 for the Middle Miocene rocks).

\section{2- Mechanical properties of carbonate rocks}

The mechanical properties of a rock are infulenced by several factors. The most effective factors are mineralogical composition, textures, microstructures, porosity, bulk density, moisture content, temperature-pressure condition, and rate of deformation (Bell, 1983).

\section{I- Indirect measurment of the uniaxial compressive strength (UCS)}

Schmidt hammer was developed in 1948 as a non-destructive tool for testing the concrete hardness (Schmidt, 1951). Then, it has been widely used by many authors for prediction of uniaxial compressive strength of rocks. Among of them are Deere and Miller (1966), Sachpazis (1990), Katz et al. (2000), Kahraman (2001), Aydin and Basu (2005), and Buyuksagis and Goktan (2007). The mean values of the Schmidt hammer rebound numbers of rock samples are used to estimate their uniaxial compressive strength by using the dry density values of these rocks and applying the chart provided by Deere and Miller (1966).

Table (4) showing the estimated uniaxial compressive strength of the studied Upper Eocene rock samples. The values of the uniaxial compressive strength range between $24.00 \mathrm{MPa}$ and $38.00 \mathrm{MPa}$ with an average of $30.78 \mathrm{MPa}$. According to the ISRM classfication (Brown, 1981), the most studied Upper Eocene rock samples are classified as medium strong rocks, except sample no. 7 is classified as weak rock. On the other hand, the estimated uniaxial compressive strength of the studied Middle Miocene rock samples range between 23.00 MPa and 84.00 MPa with an average of 37.69 MPa. 
According to the ISRM classfication (Brown, 1981), the studied rock samples are classified as weak to strong rocks (Table 5).

\section{II- Direct measurment of the uniaxial compressive strength (UCS)}

The unconfined (or uniaxial) compressive strength test is considered to be the most wide spread method to obtain rock strength. Uniaxial compressive strength is normally determined by statically loading a cylinder or cube of rock to failure, the load being applied across the upper and lower faces of the rock sample. The results obtained are in part a function of the length breadth ratio of the sample. The measured value of uniaxial compressive strength is determined as follows:

$$
\mathrm{C}_{0}=\mathrm{P} / \mathrm{A}
$$

Where $\mathrm{C}_{0}$ : measured uniaxial compressive strength; $\mathrm{P}$ : maximum applied load; A: cross section area.

According to ASTM (1986), the shape correction for the unconfiend compressive strength is:

$$
\mathrm{C}=\mathrm{C}_{0} / 0.88+(0.24 \mathrm{D} / \mathrm{L})
$$

Where C: corrected uniaxial compressive strength of an equivalent 2.00:1.00 length/diameter speciemen; $\mathrm{C}_{0}$ : measured uniaxial compressive strength of the specimen tested; D, L: diameter and length of tested rock sample respectively. The variation of C for a length/diameter ratio between 1.00 and 3.00 would be 0.89 to 1.04 .

Table (4) showing the values of the estimated direct uniaxial compressive strength of the studied Upper Eocene rock samples. The values of the uniaxial compressive strength range between 9.50 MPa and 41.43 MPa with an average of 20.49 MPa. On the other hand, the values of the direct uniaxial compressive strength of Middle Miocene rock samples range between $8.40 \mathrm{MPa}$ and $32.70 \mathrm{MPa}$ with an average of $20.71 \mathrm{MPa}$ (Table 5). According to Egyptian Code (2001) classfication, the studied rock samples are classified as medium weak to medium hard rocks.

\section{Discussion}

Skeletal fragments, crystal size, crystal shape, total orthosparite and dolomite cement, detrital materials and porosity are the most important petrographic factors that affect the carbonate rock strengths.

\section{(I) Allochem skeletal fragments vs. UCS parameters}

The surface contacts between the allochem skeletal fragments and the groundmass cemented materials are considered as micro-fractures through them, the rock can easily deformed until breakdown when subject to excess stress. Figure (14) indicates nonsignificant negative relations between the allochem skeletal fragments and the rock strength parameters, $(\mathrm{R}=-0.30$ and -0.38$)$

\section{(II) Crystal size of orthochem components vs. UCS parameters}

The percentage of neomorphic sparitic crystals (range in size from 10.00 to $50.00 \mathrm{um})$ has a positive relations with the rock strength parameters $(R=+0.43$ 
and +0.52 , Figure 15). However, the percentage of orthosparitic crystals (larger than $50.00 \mathrm{um})$ has a non-significant positive relation $(R=+0.15$ and +0.30 , Figure 15). These relations reveal that the coarse crystals (Orthosparite crystals) have longer surface contacts between them than that found between the fine crystals (Neomorphic sparite crystals) where the rock can easily deformed through these contacts due to vertical compressive stresses.

\section{(III) Crystal shape of orthochem components vs. UCS parameters}

Non-significant negative relations between the idiotopic (euhedral) crystals and the rock strength parameters $(\mathrm{R}=-0.41$ and -0.32$)$ have been recorded as shown in Figure (16). However, the Figure (16) indicates non-significant positive relations between the hypidiotopic (subhedral) crystals and the rock strength parameters $(\mathrm{R}=+0.32$ and +0.30$)$. These relations point out that, the euhedral crystals have straight surface contacts between them that are considered as straight micro-fractures that easily deformed, while the subhedral crystals have interlocked or zigzag surface contacts that increase the rock resistance against the deformation.

\section{(IV) Cementation materials and detrital components vs. UCS parameters}

Figure (17) shows the positive relations between the total orthochem and the total orthochem plus dolomite cement materials with the rock strength parameters $(R=+0.31,+0.52,+0.58$ and +0.55 respectively). Mostly nonsignificant negative relations between the quartz grains and argillaceous materials with the rock strength parameters $(R=-0.50,-0.33,-0.36$ and -0.40 respectively) have been observed in Figure (18). The results may imply that, any detrital components caused the disturbance of the main textures of the carbonate rocks and have a negative effect on their strength.

\section{(V) Porosity vs. UCS parameters}

The petrographic micro and macro porosities of primary or/and secondary origins of the carbonate rocks are usually have a random distribution. The petrographic porosity has negative relations with the rock strength parameters $(R=-0.42$ and -0.48 , Figure 19). Therefore, the increase of petrographic porosity decreases the carbonate rock strength. These relations agree with Hatzor and Palchik (1997) and Palchik and Hatzor (2004).

The diagenesis processes are affected the studied carbonate compressive strength. The compressive strength increase with increasing the dolomitization (Figure 17) and internal filling of weak planes within the carbonate rocks, while it decrease with increase the aggrading neomorphism and dissolution diagenesis processes(Figures 15 and 19 respectively).

\section{Conclusions}


This study applied multiple analyses to examine the influence of petrographic characteristics of foundation carbonate rocks collected from New Cairo City on their uniaxial compressive strength. This study revealed that; the uniaxial compressive strength of carbonate rocks increase with decrease allochem skeletal fragments, idiotopic (euhedral) crystals, detrital materials (quartz and argillaceous components) and porosity petrographic parameters. On the other hand, their uniaxial compressive strength increase with increase cemented materials, hypidiotopic (subhedral) crystals within the rock. The relationships of cemented materials crystal size with carbonate rock strength indicated that; the fine crystals (neomorphic sparite) have best relations with rock strength parameters than large crystals (orthosparite). Therefore, the presence of a considerable amount of orthosparite crystals in the carbonate rocks lead to decrease their compressive strength. The diagenesis processes are affected the studied carbonate compressive strength. The compressive strength increase with increasing the dolomitization and internal filling of weak planes within the carbonate rocks, while it decrease with increase the aggrading neomorphism and dissolution diagenesis processes.

\begin{tabular}{|c|c|c|c|}
\hline Time Unit & $\begin{array}{c}\text { Rock } \\
\text { Unit }\end{array}$ & Lithology & Description \\
\hline Pliocene & & 100008 & Cross bedded sand with few clay thin beds \\
\hline \multirow{2}{*}{ Miocene } & $\begin{array}{c}\text { Non } \\
\text { Marine }\end{array}$ & & Loose sand and gravels \\
\hline & Marine & $\frac{1}{2-2828}$ & $\begin{array}{l}\text { Sandstone, limestone, dolostone } \\
\text { interbedded with claystone beds. }\end{array}$ \\
\hline \multirow[b]{2}{*}{ Oligocene } & Basalt & Eq98; & Basaltic flows \\
\hline & $\begin{array}{l}\text { Gebel } \\
\text { Ahmer }\end{array}$ & & $\begin{array}{l}\text { Varicolored, unstratified, } \\
\text { medium to coarse-grained sands, } \\
\text { cross-bedded sandstones and } \\
\text { pebble beds with silicified wood }\end{array}$ \\
\hline $\begin{array}{l}\text { Upper } \\
\text { Eocene }\end{array}$ & $\begin{array}{l}\text { Wadi } \\
\text { Hof }\end{array}$ & w & $\begin{array}{l}\text { Claystone intercalated with } \\
\text { limestone, dolostone, marl and } \\
\text { weakly cemented sandstone. }\end{array}$ \\
\hline
\end{tabular}

$80 \mathrm{~m}$

Figure (2): Litho-Stratigraphic section of the study area.

$0 \mathrm{~m}$

ASTM (1986). Standard test method of unconfined compressive strength of intact rock core specimens, D2938: P. 390-391. 


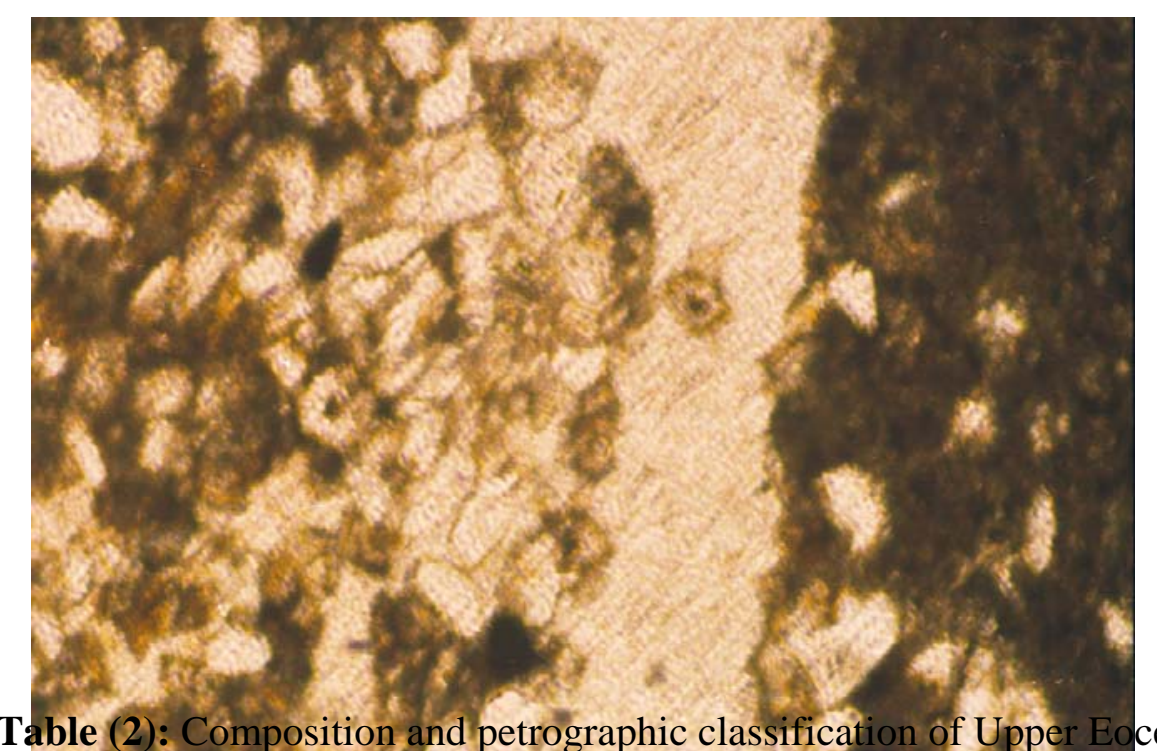

Table (2): Composition and petrographic classification of Upper Eocene carbonate samples.

\begin{tabular}{|c|c|c|c|c|c|c|}
\hline \multirow{2}{*}{$\begin{array}{l}\text { Sample } \\
\text { No. }\end{array}$} & \multirow[b]{2}{*}{$\begin{array}{c}\text { Skeletal } \\
\text { Grains } \\
\%\end{array}$} & \multirow[b]{2}{*}{$\begin{array}{l}\text { Non Skeletal } \\
\text { Grains \% }\end{array}$} & \multirow[b]{2}{*}{$\begin{array}{l}\text { Micrite } \\
\text { Matrix \% }\end{array}$} & \multicolumn{2}{|c|}{ Sparite Cement \% } & \multirow[b]{2}{*}{ Total Orthochems \% } \\
\hline & & & & $\begin{array}{c}\text { Neomorphic Sparite } \\
4 \text {-50um }\end{array}$ & $\begin{array}{l}\text { Orthosp } \\
\text { arite } \\
\text { more } \\
\text { than } \\
\text { 50um }\end{array}$ & \\
\hline 1 & 1.00 & 0.00 & 0.00 & 0.00 & 9.00 & 9.00 \\
\hline 2 & 10.00 & 0.00 & 0.00 & 0.00 & 10.00 & 10.00 \\
\hline 3 & 35.00 & 0.00 & 0.00 & 20.00 & 0.00 & 20.00 \\
\hline 4 & 0.00 & 0.00 & 0.00 & 5.00 & 0.00 & 5.00 \\
\hline 5 & 25.00 & 5.00 & 0.00 & 32.00 & 0.00 & 32.00 \\
\hline 6 & 40.00 & 0.00 & 0.00 & 25.00 & 0.00 & 25.00 \\
\hline 7 & 5.00 & 0.00 & 0.00 & 2.00 & 0.00 & 2.00 \\
\hline 8 & 1.00 & 0.00 & 0.00 & 0.00 & 5.00 & 5.00 \\
\hline 9 & 1.00 & 0.00 & 0.00 & 5.00 & 0.00 & 5.00 \\
\hline
\end{tabular}

Table (2): Continued

\begin{tabular}{|c|c|c|c|c|c|l|}
\hline \multirow{2}{*}{$\begin{array}{c}\text { Sample } \\
\text { No. }\end{array}$} & $\begin{array}{c}\text { Total Non } \\
\text { Carbonate } \\
\text { Components \% }\end{array}$ & $\begin{array}{c}\text { Porosity } \\
\mathbf{\%}\end{array}$ & $\begin{array}{c}\text { Idiotopics } \\
\mathbf{\%}\end{array}$ & $\begin{array}{c}\text { Hypidiotopics } \\
\mathbf{\%}\end{array}$ & $\begin{array}{c}\text { Xenotopics } \\
\mathbf{\%}\end{array}$ & Folk (1s \\
\hline $\mathbf{1}$ & 38.00 & 5.00 & 80.00 & 20.00 & 0.00 & Sandy Dolomicrospa \\
\hline $\mathbf{2}$ & 37.00 & 8.00 & 85.00 & 15.00 & 0.00 & Sandy Dolomicrospa \\
\hline $\mathbf{3}$ & 35.00 & 5.00 & 40.00 & 60.00 & 0.00 & Sandy Biomicrospari \\
\hline $\mathbf{4}$ & 37.00 & 3.00 & 60.00 & 40.00 & 0.00 & Sandy Argillaceous \\
\hline $\mathbf{5}$ & 36.00 & 3.00 & 30.00 & 50.00 & 20.00 & Sandy Biomicrospari \\
\hline $\mathbf{6}$ & 30.00 & 5.00 & 0.00 & 100.00 & 0.00 & Sandy Biomicrospari \\
\hline $\mathbf{7}$ & 46.00 & 7.00 & 80.00 & 20.00 & 0.00 & Sandy Dolomicrite \\
\hline $\mathbf{8}$ & 34.00 & 5.00 & 0.00 & 80.00 & 20.00 & Sandy Dolomicrospa \\
\hline $\mathbf{9}$ & 37.00 & 2.00 & 10.00 & 90.00 & 0.00 & Sandy Argillaceous \\
\hline
\end{tabular}


Aydin A, Basu A. (2005): The Schmidt hammer in rock material characterization. Eng. Geol., V.81, P. 1-14.

Bell, F. G. (1983): Fundamentals of engineering geology, Butterworth, London. 648 P.

Brown, E. T. (Ed.), (1981). Rock Characterization, Testing and Monitoring, ISRM Suggested Methods. Pergamon, Oxford. 211 P.

Buyuksagis, I. S., and Goktan, R. M. (2007): Technical Note: The effect of Schmidt hammer type on uniaxial compressive strength prediction of rock. Inter. Jour. of Rock Mech. and Mining Sciences, V. 44, P. 299-307.

Deere D. U., and Miller, R. P. (1966): Engineering classification and index properties for intact rock, Air Force Weapons Lab. Tech. Report, No. AFNL-TR, P. 65-116, Kirtland Base, New Mexico.

Dunham, R. J. (1962): Classification of carbonate rocks according to depositional texture. Amer. Ass. Petrol. Geol., V.1, P. 108-121.

Eberhardt, E., Stimpson, B., and Stead, D. (1999): Effects of grain size on the initiation and propagation thresholds of stress-induced brittle fractures. Rock Mech. and Rock Eng. V. 32 (2), P. 81-99.

Egyptian Code (2001): Soil mechanics, design and construction foundation.

Folk, R. L. (1959): Practical petrographical classification of limestones. Amer. Ass. Petrol. Geol., Bull. 43/1, P. 1-38.

Folk, R. L. (1962): Spectral subdivision of limestone types. Amer. Ass. Petrol. Geol., V.1, P. 62-84.

Hatzor, Y. H., Palchik, V. (1997): The influence of grain size and porosity on crack initiation stress and critical flaw length in dolomites. Inter. Jour. Rock Mech. and Mining Sciences V. 34(5), P. 805-816.

Hatzor, Y. H., Plachik, V. (1998): A microstructure-based failure criterion for Aminadav dolomites. Inter. Jour. of Rock Mech. and Mining Sciences V. 35, P. 797-805.

Hugman, R. H. and Freidman, M. (1979): Effects of texture and composition on mechanical behaviour of experimentally deformed carbonated rocks: Amer. Ass. Petrol. Geol., Bull., 63(9), 1478-1489.

Kahraman, S. (2001): Evaluation of simple methods for assessing the uniaxial compressive strength of rock: Inter. Jour. of rock mech. and mining sciences, V. 38, P. 981-994.

Katz, O., Reches, Z., and Roegiers, J. C. (2000): Technical Note; Evaluation of mechanical rock properties using a Schmidt hammer: Inter. Jour. of rock mech. and mining sciences, V. 37, P. 723-728.

Onodera, T. F, and Asoka, K. H. M. (1980): Relation between texture and mechanical properties of crystalline rocks: Bull. Inter. Assoc. Eng. Geol., V. 22, P. 173-177.

Palchik, V., and Hatzor, Y. H. (2004): Technical Note: The influence of porosity on tensile and compressive strength of porous chalks. Rock Mech. and Rock Eng. V. 37 (4), P. 331-341.

Sachpazis, C. I. (1990): Correlating Schmidt hardness with compressive strength and Young's Modulus of carbonate rocks. Bull. Inter. Assoc. Eng. Geol., 42:75-84.

Schmidt, E. (1951): A non-destructive concrete tester. Concrete; V.59 (8): P. 34-35. 